\title{
Undernutrition in sheep. The effect of supplementation with protein on protein accretion
}

\author{
BY I. FATTET*, F. D. DEB. HOVELL†, E. R. ØRSKOV, D. J. KYLE, \\ K. PENNIE AND R. I. SMART \\ Rowett Research Institute, Bucksburn, Aberdeen AB2 9SB
}

(Received 30 August 1983 - Accepted 19 June 1984)

1. In a comparative-slaughter experiment, individually rationed wether lambs initially of $42 \mathrm{~kg}$ were given 235 , 362 or $456 \mathrm{~kJ}$ metabolizable energy (ME) $/ \mathrm{kg}$ live weight $(\mathrm{LW})^{0 \cdot 75}$ per d as sodium hydroxide-treated barley straw with urea (six lambs per treatment), or $\mathrm{NaOH}$-treated barley straw with urea plus $125 \mathrm{~g} / \mathrm{d}$ white-fish meal to give 307 or $488 \mathrm{~kJ} \mathrm{ME} / \mathrm{kg} \mathrm{LW}^{0 \cdot 75}$ per d (seven lambs per treatment) for $92 \mathrm{~d}$.

2. All unsupplemented lambs lost both fat and body protein. The changes in fat were $-3.53,-2 \cdot 75$ and $-1 \cdot 40$ (SE 0.59 ) $\mathrm{kg}$ (initial value $8.6 \mathrm{~kg}$ ), and the changes in body protein were $-0.47,-0.09$ and -0.14 (SE 0.13 ) $\mathrm{kg}$ (initial value $4.9 \mathrm{~kg}$ ) for the three unsupplemented groups respectively. When supplemented with fish meal, fat was again lost as -1.53 and -0.93 (SE 0.55 ) $\mathrm{kg}$, but wool-free body protein was increased, and gains were 0.48 and 0.89 ( $\mathrm{SE} 0.12) \mathrm{kg}$ for the two supplemented groups respectively. All animals lost wool-free body energy, total changes being $-150,-111,-59$ and -49 and $-16 \mathrm{MJ}$ respectively. When corrected to an equal ME intake the supplemented lambs, when compared with the unsupplemented lambs, gained (instead of losing) body protein $(P<0.001)$ and lost less fat $(P<0.05)$. Wool growth did not respond to supplemental protein, but was related to $\mathrm{ME}$ intake with an increase of $0.78 \mathrm{~g}$ wool fibre for each additional $\mathrm{MJ} \mathrm{ME}$.

3. The maintenance requirements of the unsupplemented and supplemented groups respectively were estimated by regression analysis to be 554 and $496 \mathrm{~kJ} \mathrm{ME} / \mathrm{kg} \mathrm{LW} \mathbf{W}^{0.75}$ per $\mathrm{d}$. The apparent utilization of ME below energy equilibrium $\left(k_{m}\right)$ was 0.31 (SE 0.08 ) for the unsupplemented animals, and 0.12 (SE 0.10$)$ for the supplemented animals, well below a $k_{m}$ of $0 \cdot 70$ which current UK standards (Agricultural Research Council, 1980) would predict. Most of these differences could be reconciled if basal metabolism was assumed not to be constant.

4. It is concluded that lambs in negative energy balance can continue lean body growth at the expense of body fat, provided sufficient dietary protein is available. It is also concluded that since the animals at the lowest $\mathrm{ME}$ intakes required less ME than predicted by current feeding standards, the effect was that it would have been difficult to distinguish between the apparent utilization of ME for maintenance $\left(k_{m}\right)$ and for fattening $\left(k_{f}\right)$.

That the nitrogen requirements of ruminants are a combination of the needs of the host animal and of the rumen micro-organisms has long been recognized. However, only recently have there been attempts to describe ruminant protein requirements as an integration of these separate components (Institut National de la Recherche Agronomique (INRA), 1978; Agricultural Research Council (ARC), 1980), for the complex and inter-related activities of the micro-organisms and host are difficult to measure.

The development of the total-infusion technique with which ruminants are entirely maintained by the intragastric infusion of volatile fatty acids and protein (Ørskov et al. 1979) has provided the means whereby the $\mathrm{N}$ metabolism of the host animal may be measured without the complication of a rumen microbial population. Recent experiments using the total-infusion technique have shown the basal $\mathrm{N}$ excretion of both cattle (Ørskov \& MacLeod, 1982) and sheep (Hovell et al. 1983a) to be greater than that described by the ARC (1980). It has also been shown by means of total infusion that both sheep (Hovell et al. $1983 \mathrm{~b}$ ) and cattle (Ørskov \& MacLeod, 1982) had a positive $\mathrm{N}$ balance even when in negative energy balance, provided sufficient protein was given. The implications of these two findings to the normally fed animal are: first, that if the energy intake (as fermentable

\footnotetext{
* Present address: Facultad de Agronomia, Departmento de Zootecnia, Av. San Martin 4453, 1417 Buenos Aires, Argentina.

$\dagger$ For reprints.
} 
substrate) of the host animal is below energy maintenance, then the amount of microbial protein that will be synthesized (ARC, 1980) would not be sufficient to maintain the protein status of the host animal; second, that a growing animal should be capable of making lean-body growth at the expense of body fat, provided that it has a sufficient supply of protein. The experiment to be reported here was designed to test whether those two findings made with totally infused animals in trials of relatively short duration, could be confirmed in an experiment of longer duration with animals fed normally.

\section{EXPERIMENTAL}

Animals and treatments. Forty-four Suffolk wether lambs initially of $42 \mathrm{~kg}$ were used. They were offered sodium hydroxide-treated barley straw to appetite for a 2-week initial period before being allocated at random into an initial-slaughter group of twelve lambs or to one of five treatment groups with six or seven lambs per treatment. The experimental period was of $92 \mathrm{~d}$. The treatments were: low straw (LS), $\mathrm{NaOH}$-treated barley straw plus urea, minerals and vitamins, subsequently estimated to give $235 \mathrm{~kJ}$ metabolizable energy (ME) $/ \mathrm{kg}$ live weight $(\mathrm{LW})^{0 \cdot 75}$ per d; medium straw (MS), as LS, but with $362 \mathrm{~kJ} \mathrm{ME} / \mathrm{kg} \mathrm{LW}^{0.75}$ per d; straw to appetite (AS); low-straw and fish meal (LS-FM), as LS, but supplemented with $125 \mathrm{~g}$ white-fish meal/d; high-straw and fish meal (HS-FM), as LS-FM, but with the treated straw subsequently estimated to supply $384 \mathrm{~kJ} \mathrm{ME} / \mathrm{kg} \mathrm{LW}^{0-75}$ per d. In all cases the level of intake was fixed in relation to the initial $(24 \mathrm{~h})$ fasted weight and kept constant throughout the experiment.

Housing, management and diets. All animals were kept indoors in individual pens. The diet was given twice daily, with water available at all times. During the experiment they were injected twice with a multi-vitamin supplement (Duphofral multivit, Philips-Duphor B.V., Amsterdam, Holland). The NaOH-treated barley straw was prepared every 7-12 d complete with urea, minerals and vitamins, as described by Hovell et al. $(1983 a)$, the only difference being that urea was added at a rate of $20 \mathrm{~g} / \mathrm{kg}$ dry matter (DM), rather than $18 \mathrm{~g} / \mathrm{kg}$ DM. The fish meal was mixed with molasses to increase palatability, the proportions being: $125 \mathrm{~g}$ fish meal and $50 \mathrm{~g}$ molasses on an air-dry basis. The lambs on treated straw alone also received $50 \mathrm{~g}$ molasses/d, mixed with part of their straw ration. The treated straw, fish meal and molasses contained 844,818 and $835 \mathrm{~g}$ organic matter $/ \mathrm{kg}$ DM respectively and the fish meal and molasses contained 119.4 and $7.6 \mathrm{~g} \mathrm{~N} / \mathrm{kg}$ DM respectively.

\section{Measurements}

Daily weight gain. Lambs were weighed twice weekly before being fed in the morning, the first weight being taken $16 \mathrm{~d}$ after allocation to treatment. Daily gain was calculated as the slope of the regression LW $v$. time, for each individual.

Digestibility. The digestibility of the diet was determined towards the end of the experiment. Six further lambs were used. A bulked sample of straw (bulked from the various batches made during the course of the main experiment) was offered so as to supply an estimated $325 \mathrm{~kJ} \mathrm{ME} / \mathrm{kg} \mathrm{LW}^{0} \cdot 75$ per d with the addition of $50 \mathrm{~g}$ molasses, and with or without $125 \mathrm{~g}$ fish meal. The adaptation period was of 2 weeks followed by a total collection of faeces for $7 \mathrm{~d}$. A change-over design was used, three lambs being supplemented with fish meal in each period.

Energy intake. Uneaten feed was collected daily and bulked on a weekly basis, so as to calculate DM intake. ME intake was calculated with the assumption of $15.58 \mathrm{MJ} \mathrm{ME} / \mathrm{kg}$ digestible organic matter (ARC, 1980). The organic matter digestibility of the white-fish meal was assumed to be 0.90 and that of the molasses 1.00 . The digestibility of the $\mathrm{NaOH}$-treated straw was then calculated from the values obtained in the digestibility trial and corrected for molasses and fish meal as described above. 
Fish meal degradability. Degradability in the rumen was measured using the nylon-bag technique (Mehrez \& Ørskov, 1977). Samples of $5 \mathrm{~g}$ were incubated for 8, 24, 48 and $72 \mathrm{~h}$, on two occasions, with three sheep each time. The rate of outflow of chrome-mordanted fish meal from the rumen was measured using the six lambs of the digestibility trial, and using the method of rectal sampling described by Elimam \& Ørskov (1981). Effective degradability was then calculated (Ørskov \& McDonald, 1979).

Slaughter procedure. Each lamb was shorn the day before slaughter which was then carried out at a commercial abattoir. After slaughter the alimentary tract was emptied and weighed. The organs, the omental, mesenteric and perirenal fat, head, feet and skin (after the removal of the wool with fine clippers) were weighed and then minced together to give the non-carcass component. The commercial carcass was cut down the spine, and the left side minced for chemical analysis separately from the non-carcass component. Blood and evaporative losses between slaughter and weighing were not measured.

Chemical analysis. Samples of the minced carcass and non-carcass components were freeze-dried for chemical analysis. Fat was determined by the chloroform-methanol method of Atkinson et al. (1972) and Kjeldahl $\mathrm{N}$ by the automated method of Davidson et al. (1970). Ash was determined by ashing at $500-550^{\circ}$, and DM by drying the freeze-dried sample at $100^{\circ}$ for $48 \mathrm{~h}$. The wool was weighed, coarsely minced and a representative sample thoroughly washed with hot water and a detergent, dried at $100^{\circ}$ and then weighed; this weight was termed clean dry fleece. The energy content of the protein of the body $(\mathrm{N} \times 6.25)$ and the clean dry fleece, was taken to be $23.6 \mathrm{MJ} / \mathrm{kg}$ and of the fat $39.3 \mathrm{MJ} / \mathrm{kg}$ (ARC, 1980).

Body composition. The wool-free empty-body-weight (WF-EBW) was calculated by summing the weights of the different components (carcass, organs and mesenteric, omental and perirenal fat). Body water was calculated as the difference between the WF-EBW and the sum of the weights of fat, protein and ash. The total empty-body-weight (EBW) was calculated as the sum of WF-EBW and wool weight. The initial composition of the experimental animals was calculated using regression equations derived from the initialslaughter group, with initial overnight-fasted $\mathrm{LW}$ as the independent variable.

Mean metabolic $L W(M M L W)$. This was used as the basis for subsequent calculations and was calculated as the mean of the calculated LW based on EBW (estimated at the start and measured at the end of the experiment) and corrected to a standard digesta load. This was done so as to eliminate any treatment effect on $\mathrm{LW}$ caused by differences in the weight of the contents of the gastrointestinal tract. EBW was therefore converted into LW by adding a standardized allowance for digesta load taken from the ARC (1980): $\mathrm{LW}=1.09$ $\mathrm{EBW}+5.0$ and an estimated blood loss (0.051 EBW) (I. McDonald, personal communication).

Statistical analysis. The standard errors presented in the tables are based on pooled estimates of within-treatment variation. If there were differences between treatments in variability, then statistical significance was tested by means of the Mann-Whitney $U$ test. When this test was applied, the conclusions did not differ from those which would follow from the use of the standard error as presented in the tables. Regressions were calculated changes in $\mathrm{LW}$ and body composition $v$. ME intake within main treatments (unsupplemented straw $n 18$, fish meal-supplemented straw $n 14$ ). In no case did the slopes of the regressions differ $(P<0 \cdot 10)$ and therefore the combined slope was calculated and used to calculate adjusted means for main treatment comparisons.

RESULTS

Straw digestibility. The organic matter digestibility of the $\mathrm{NaOH}$-treated barley straw when given without fish meal was 0.64 (SE 0.020) and when given with fish meal was 0.68 (SE 0.034). These values were not statistically significantly different. However, the difference was taken 


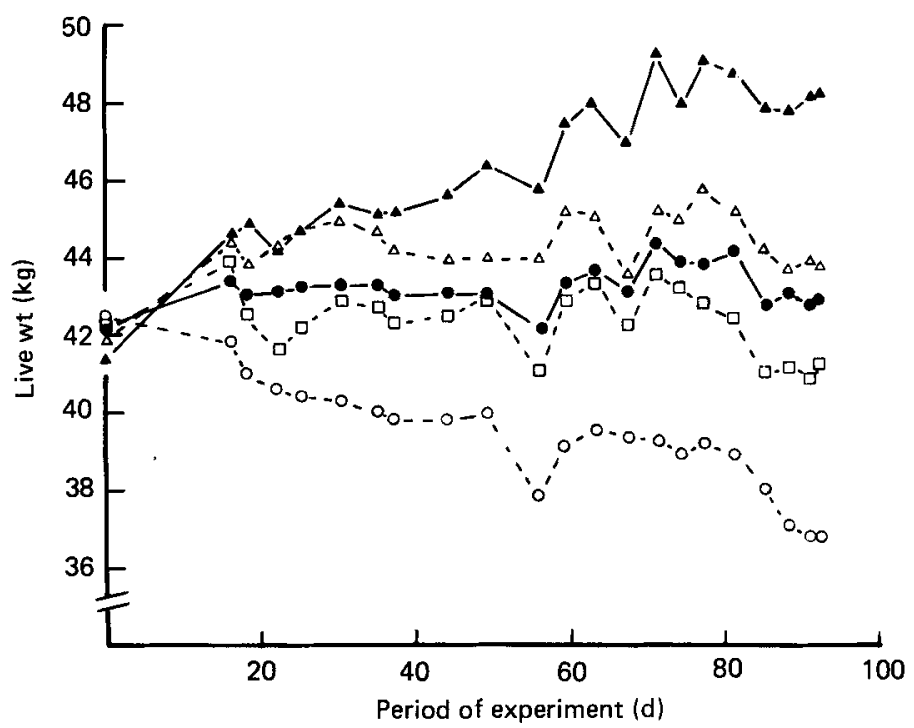

Fig. 1. Changes in live weight $(\mathrm{kg})$ of wether lambs given sodium hydroxide treated barley straw and urea with $(\mathbf{O}, \Delta)$ or without $(\mathrm{O}, \square, \Delta) 125 \mathrm{~g} / \mathrm{d}$ white-fish meal and equivalent to a total of $307(\mathrm{O})$, $488(\Delta), 235(\mathrm{O}), 326(\triangle), 456(\square) \mathrm{kJ}$ metabolizable energy $/ \mathrm{kg}$ live weight ${ }^{075}$ per $\mathrm{d}$.

into account and when calculated from these values, the energy value of the straw given alone was $8.48 \mathrm{MJ} \mathrm{ME} / \mathrm{kg} \mathrm{DM}$ and $8.89 \mathrm{MJ} \mathrm{ME} / \mathrm{kg}$ DM when given with fish meal. These values were used in subsequent calculations.

Energy intake. The energy intakes (ME kJ/kg LW ${ }^{0 \cdot 75}$ per $\mathrm{d}$ from straw plus molasses plus fish meal) are given in Table 1. The intakes of straw by the lambs on the LS and LS-FM treatments were the same, and the difference in daily ME intake $\left(235 v .307 \mathrm{~kJ} / \mathrm{kg} \mathrm{LW}^{0.75}\right)$ was due to the contribution of the fish meal. The intake of straw by the HS-FM animals was, as planned, between that of the MS and AS animals. The total daily ME intake of the HS-FM animals was slightly greater $(P<0.001)$ than that of the AS animals $\left(488 v .456 \mathrm{~kJ} / \mathrm{kg} \mathrm{LW}^{0 \cdot 75}\right.$ ). Two lambs (one on the LS-FM treatment and one on the HS-FM treatment) refused some fish meal. There was no evidence that the body composition of these animals differed from others on the same treatment, and therefore they have been included in the analysis of the results. (The respective intakes of fish meal were 88 and $108 \mathrm{~g} \mathrm{DM} / \mathrm{d}$ of the $122 \mathrm{~g} \mathrm{DM}$ offered.)

Degradability of the fish meal. The rate of outflow of chrome-mordanted fish meal measured with the six lambs on the digestibility trial was 0.049 (SE 0.0028)/h which, when combined with the determined degradation curve of the fish-meal protein, gave an effective degradability for the fish meal protein of 0.416 (SE 0.0084) (Ørskov \& McDonald, 1979).

$L W$ gain. The growth of the lambs is shown in Fig. 1, and the initial and final weights and daily gain in Table 1 . Two initial weights are shown in Table 1 . The allocation weight was that which was obtained after a $24 \mathrm{~h}$ fast, and a calculated initial weight, which is the intercept at zero time of the individual growth regressions. As can be seen from Fig. 1 the difference between these two initial weights represents changes in weight which were complete by $16 \mathrm{~d}$, and were probably due to differences in the amount of digesta (fill) in the animals. Although Table 1 shows a clear trend in increasing rate of LW gain as the amount of straw eaten increased and also when fish meal was given, only the LS and HS-FM treatments could be distinguished statistically from other treatments. 
Table 1. Live weights, daily gain and food intake of lambs given sodium hydroxide-treated barley straw and urea with (LS-FM, HS-FM) or without (LS, MS, AS) supplemental fish meal for $92 d$

\begin{tabular}{|c|c|c|c|c|c|c|}
\hline Treatment* ${ }^{*}$. & LS & MS & AS & LS-FM & HS-FM & $\begin{array}{l}\text { Approximate } \\
\text { SE of mean } \\
\text { ( } 27 \mathrm{df})\end{array}$ \\
\hline No. of lambs per treatment & 6 & 6 & 6 & 7 & 7 & \\
\hline Allocation wt $(\mathrm{kg}) \dagger$ & $42 \cdot 4$ & $42 \cdot 2$ & $41 \cdot 9$ & $42 \cdot 2$ & $41 \cdot 4$ & $1 \cdot 1$ \\
\hline Initial wt $(\mathrm{kg}) \ddagger$ & 41.9 & $43 \cdot 1$ & $44 \cdot 5$ & $43 \cdot 1$ & $43 \cdot 0$ & $1 \cdot 3$ \\
\hline Final wt $(\mathrm{kg}) \ddagger$ & $37 \cdot 6$ & $42 \cdot 1$ & $44 \cdot 5$ & $43 \cdot 2$ & $49 \cdot 1$ & $1 \cdot 2$ \\
\hline Daily wt gain $(\mathrm{g}) \ddagger$ & -47 & -13 & 0 & 3 & 68 & 8 \\
\hline MMLW $\left(\mathrm{kg} \mathrm{LW} W^{0.75}\right) \S$ & $16 \cdot 2$ & $16 \cdot 6$ & 16.9 & $17 \cdot 1$ & $17 \cdot 6$ & 0.29 \\
\hline \multicolumn{7}{|l|}{ Daily DM intake (g) } \\
\hline Treated Straw & 397 & 657 & 859 & 392 & 760 & - \\
\hline Molasses & 43 & 43 & 43 & 43 & 43 & - \\
\hline Fish meal & - & - & - & 117 & 120 & - \\
\hline $\mathrm{ME}\left(\mathrm{kJ} / \mathrm{kg} \mathrm{LW}^{0.75}\right.$ per d)\| & 235 & 362 & 456 & 307 & 488 & 6 \\
\hline
\end{tabular}

LS, low straw; MS, medium straw; AS, straw to appetite; LS-FM, low straw and fish meal; HS-FM, high straw and fish meal; MMLW, mean metabolic live weight; DM, dry matter; ME, metabolizable energy; LW, live weight.

* For details, see p. 562.

+ After 24 h fast.

$\ddagger$ Calculated from individual regressions of live weight $v$. time (see p. 562).

$\S$ Based on empty body-weight corrected to a standard digesta content (see p. 563).

il Based on a measured digestibility for the straw (see p. 563).

Table 2. Regression equations derived from the initial-slaughter group of twelve lambs with the overnight fasted live weight $(L W)$ as the independent variable

\begin{tabular}{|c|c|c|c|c|c|c|}
\hline Dependent variable & Mean & SD & Regression equation & $\begin{array}{c}\text { SE } \\
\text { of slope }\end{array}$ & $\begin{array}{l}\text { Residual } \\
\text { SD }\end{array}$ & $\begin{array}{c}\text { Statistical } \\
\text { significance } \\
\text { of regression }\end{array}$ \\
\hline LW (kg) & $42 \cdot 0$ & $4 \cdot 7$ & - & - & - & \\
\hline Wool-free empty-body-wt $(\mathrm{kg})$ & $31 \cdot 0$ & $3 \cdot 4$ & $0.67(\mathrm{LW})+2.38$ & 0.084 & $1 \cdot 31$ & *** \\
\hline Unwashed dry fleece $(\mathrm{kg})$ & $2 \cdot 07$ & 0.33 & - & - & - & NS \\
\hline Clean dry wool fibre $(\mathrm{kg})$ & $1 \cdot 10$ & $0 \cdot 21$ & - & - & - & NS \\
\hline \multicolumn{7}{|l|}{ Wool-free empty-body: } \\
\hline Water $(\mathrm{kg})$ & $16 \cdot 19$ & 1.59 & $0 \cdot 31(\mathrm{LW})+3 \cdot 17$ & $0 \cdot 040$ & 0.69 & $* * *$ \\
\hline Nitrogen $\times 6.25(\mathrm{~kg})$ & 4.94 & 0.48 & $0.08(L W)+1.58$ & 0.019 & 0.29 & * \\
\hline Fat $(\mathrm{kg})$ & $8 \cdot 59$ & 1.75 & $0.26(L W)-2.33$ & 0.082 & 1.29 & * \\
\hline Ash (kg) & $1 \cdot 26$ & $0 \cdot 11$ & $0.018(\mathrm{LW})+0.50$ & 0.005 & 0.08 & * \\
\hline Energy (MJ) & 454 & 74 & $12 \cdot 3 \quad(\mathrm{LW})-62$ & $3 \cdot 0$ & 47 & * \\
\hline
\end{tabular}

NS, not significant $(P>0 \cdot 10) . \quad * P<0.05,{ }^{* * *} P<0.001$.

Initial and final body composition. The regression equations derived from the initialslaughter group which were used to estimate initial composition are given in Table 2 . The equation for clean dry wool fibre was very much influenced by one animal which was among the lightest, but had a very heavy fleece with $1.59 \mathrm{~kg}$ clean dry fibre. When this animal was removed from the analysis, the slope of the regression became -0.0097 (SE 0.0089) and therefore the average value for the initial group was used.

The final composition of the experimental animals is given in Table 3. There was a 
Table 3. Final composition and changes in composition of lambs given sodium hydroxidetreated straw and urea with (LS-FM, HS-FM) or without ( $L S, M S, A S)$ supplemental fish meal for $92 d$

\begin{tabular}{|c|c|c|c|c|c|c|}
\hline Treatment*... & LS & MS & AS & LS-FM & HS-FM & $\begin{array}{l}\text { Approximate } \\
\text { SE of mean } \\
(27 \mathrm{df})\end{array}$ \\
\hline No. of lambs per treatment & 6 & 6 & 6 & 7 & 7 & - \\
\hline ME intake $\left(\mathrm{kJ} / \mathrm{kg} \mathrm{LW}^{075}\right.$ per $\left.\mathrm{d}\right) \dagger$ & 235 & 362 & 456 & 307 & 488 & 6 \\
\hline Live wt $(\mathrm{kg})$ & $37 \cdot 6$ & $42 \cdot 1$ & $44 \cdot 5$ & $43 \cdot 2$ & $49 \cdot 1$ & $1 \cdot 2$ \\
\hline Wool-free empty-body-wt & & & & & & \\
\hline (WF-EBW) (kg) & $26 \cdot 2$ & $28 \cdot 3$ & $30 \cdot 1$ & $31 \cdot 8$ & 34.7 & $1 \cdot 0$ \\
\hline Digesta $(\mathrm{kg})$ & $5 \cdot 3$ & $6 \cdot 5$ & 6.9 & $5 \cdot 0$ & $7 \cdot 2$ & $0 \cdot 3$ \\
\hline Clean dry wool fibre $(\mathrm{kg})$ & 1.32 & 1.63 & 1.71 & $1 \cdot 60$ & 1.73 & $0 \cdot 11$ \\
\hline \multicolumn{7}{|l|}{ Wool-free empty-body (WF-EB): } \\
\hline Water $(\mathrm{kg})$ & $15 \cdot 26$ & $16 \cdot 20$ & 16.87 & $17 \cdot 84$ & 19.99 & 0.51 \\
\hline Nitrogen $\times 6.25(\mathrm{~kg})$ & $4 \cdot 50$ & $4 \cdot 86$ & 4.79 & 5.43 & 5.78 & $0 \cdot 18$ \\
\hline Fat $(\mathrm{kg})$ & $5 \cdot 17$ & 5.89 & $7 \cdot 16$ & $7 \cdot 11$ & $7 \cdot 50$ & 0.67 \\
\hline Ash (kg) & 1.27 & 1.29 & 1.27 & $1 \cdot 35$ & 1.45 & 0.08 \\
\hline Energy (MJ) & 309 & 346 & 394 & 408 & 431 & 28 \\
\hline \multicolumn{7}{|l|}{ Total change during experiment $(\mathrm{kg})$ : } \\
\hline Live wt & $-4 \cdot 32$ & $-1 \cdot 23$ & 0.08 & 0.29 & $6 \cdot 22$ & 0.73 \\
\hline WF-EBW & $-5 \cdot 05$ & -2.85 & -0.80 & 0.64 & $4 \cdot 18$ & 0.61 \\
\hline Clean dry wool fibre & $0 \cdot 22$ & 0.53 & $0 \cdot 61$ & $0 \cdot 50$ & 0.63 & $0 \cdot 11$ \\
\hline \multicolumn{7}{|l|}{ WF-EB: } \\
\hline Water $(\mathrm{kg})$ & -1.06 & 0.05 & 0.71 & 1.59 & 4.00 & 0.41 \\
\hline $\mathrm{N} \times 6 \cdot 25(\mathrm{~kg})$ & -0.47 & -0.09 & $-0 \cdot 14$ & 0.48 & 0.89 & 0.12 \\
\hline Fat $(\mathrm{kg})$ & $-3 \cdot 53$ & $-2 \cdot 75$ & $-1 \cdot 40$ & $-1 \cdot 53$ & -0.93 & 0.55 \\
\hline Ash $(\mathrm{kg})$ & 0.00 & 0.03 & 0.02 & $0 \cdot 10$ & 0.21 & 0.07 \\
\hline Energy (MJ) & -150 & -111 & -59 & -49 & -16 & 22 \\
\hline
\end{tabular}

LS, low straw; MS, medium straw; AS, straw to appetite; LS-FM, low straw and fish meal; HS-FM, high straw and fish meal; ME, metabolizable energy; LW, live weight.

* For details, see Table 1 and p. 562.

$\dagger$ Including ME of fish meal for the LS-FM and MS-FM groups.

progressive decrease in the WF-EBW as the amount of straw given was decreased. There was also a clear effect of fish meal, for the supplemented animals maintained or increased their EBW. Indeed, the LS-FM lambs had greater EBW $(P<0.05)$ than the MS lambs, although they consumed less energy (Table 1). The effect of the treatments is more clearly demonstrated when expressed as the change in EBW during the experiment, and it can be seen (Table 3) that the unsupplemented animals lost weight and the supplemented animals gained weight. The changes in composition made during the experiment are also shown by Table 3. All the lambs lost fat during the experiment and all animals lost body energy. However, whereas all the straw-fed lambs lost protein (statistically not significant in the case of the MS and AS groups), the animals supplemented with fish meal gained protein $(P<0.001)$ whilst losing fat.

The rates of LW change and changes in body composition expressed in relation to MMLW $\left(\mathrm{kg} \mathrm{LW}^{\mathbf{0} 75}\right)$ are presented in Table 4. The results were first calculated within diets (straw alone or straw plus fish meal). However, since the slopes of the regressions did not differ significantly between treatments for any factor, the combined slopes are presented. Comparison was made on the basis of means adjusted to a ME intake of $488 \mathrm{~kJ} / \mathrm{kg} \mathrm{LW}^{0.75}$ per $d$ (the mean intake of the HS-FM group) and these values are also presented in Table 4. When supplemented with protein as fish meal, the lambs lost fat and gained protein. The 


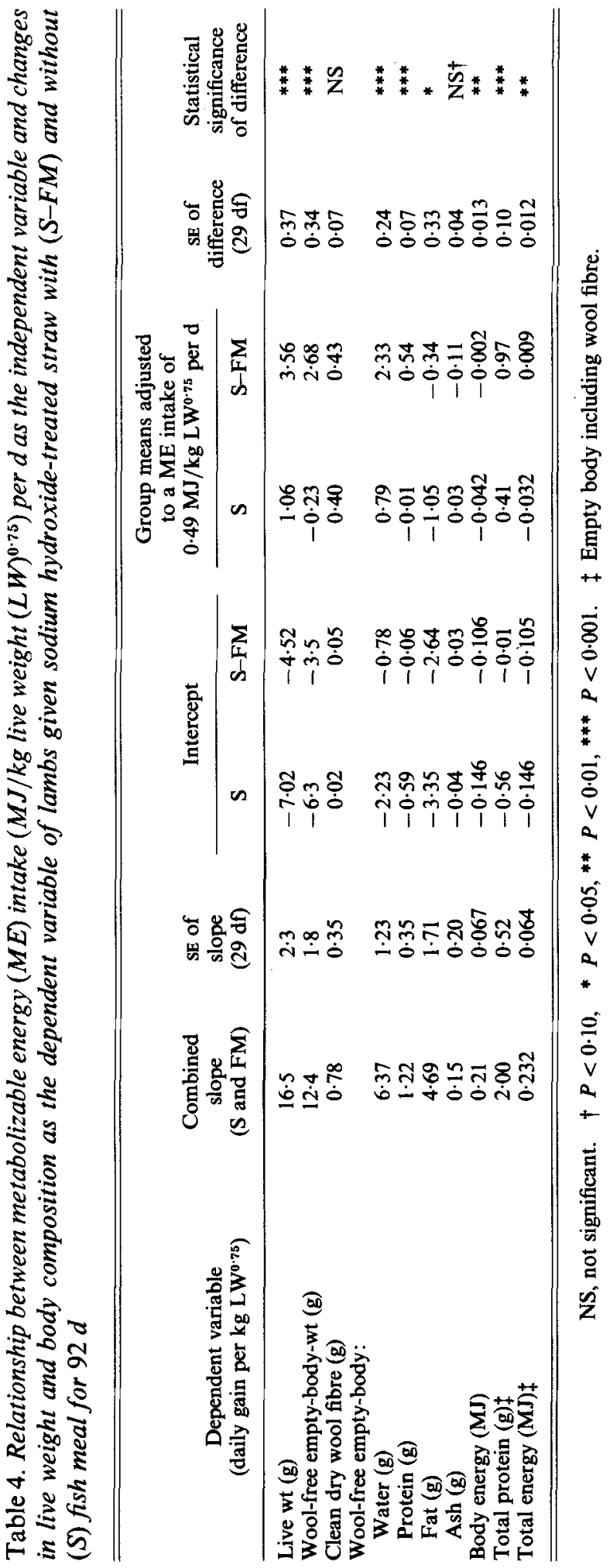


rate of protein gain was significantly $(P<0.001)$ greater than the loss of protein by the lambs not given supplementary protein, and the rate of fat loss significantly less $(P<0.05)$ than that of the lambs not given supplementary protein. These changes were also reflected in the changes in the body energy of the two groups $(P<0.01)$. The changes in body protein and fat were made to both the carcass and non-carcass components of the wool-free empty-body (WF-EB), and the relative proportions of WF-EB protein and fat in the carcass and non-carcass components did not change significantly (Table 5).

Body viscera. The fresh weights of the main body viscera are shown in Table 5. There were clear and significant treatment effects, and therefore covariance analysis with WF-EBW or carcass protein as the covariate was used to remove any effect of body size. The initial group was not included in this analysis. The regression coefficients were significant $(P<0.05-P<0.01)$ for all viscera except for the gastrointestinal tract. Correction for WF-EBW was the more effective in reducing the variance ratio which was reduced in all cases, and only that for liver weight $(P<0.001)$ remained statistically significant, although that for reticulo-rumen weight approached statistical significance $(P<0 \cdot 10)$. The weight for liver and reticulo-rumen corrected to the mean WF-EBW of $30.3 \mathrm{~kg}$ were (with approximate SE); 410, 458, 498, 540 and 594 (SE 15) $\mathrm{g}$ and 756, 797, 802, 765 and 892 (SE 32) $\mathrm{g}$ for the LS, MS, AS, LS-FM and HS-FM groups respectively. The results suggest that liver weights were influenced by both feeding level and protein supplementation, that reticulorumen and gastrointestinal tract (Table 5) weights were more influenced by feeding level than by protein supplementation and that the remainder of the apparent effects shown in Table 5 were eliminated when corrected for differences in WF-EBW.

\section{DISCUSSION}

$L W$ gain. The response to supplementation with fish meal is in agreement with the results of an earlier experiment (Hovell et al. 1983 b) in which the average growth response to fish meal was 20 (SE 11) g LW/d with $42-\mathrm{kg}$ lambs. The greater response to protein in the experiment reported here was to be expected, since the energy intake of the lambs in the previous experiment was higher $\left(505-706 \mathrm{~kJ} / \mathrm{kg} \mathrm{LW}^{0.75}\right.$ per d) than the $235-488 \mathrm{~kJ} / \mathrm{kg} \mathrm{LW}^{0.75}$ per $\mathrm{d}$ achieved here. This lower energy level is in the range where a better response to supplementary protein can be expected due to the greater deficit (for the host animal) of microbial protein (Hovell et al. 1983a). However, the changes in LW were not simple, for they included pronounced changes in body composition.

\section{Body composition}

Wool. Wool growth continued during undernutrition (Table 3) and there was a clear response to energy but not to protein (Table 4). It is generally considered that the sulphur-containing amino acids are usually first limiting for wool growth (Downes et al. 1976) and on this basis a response to fish meal would have been expected since microbial protein is limiting in methionine and cystine (Storm \& Ørskov, 1983). Colebrook et al. (1968) reported a positive relationship between wool growth and protein intake and, of a variety of proteins tested, the response to fish meal was consistently high. Certainly our results do not conform to the conclusion of Reis (1969) ${ }^{\circ}$... that the energetic requirements for wool growth are largely satisfied at low intakes of energy and that the major requirement is then specifically for amino acids'. The absence of a response to protein in the experiment reported here may have been due to true differences in the type of sheep used by ourselves, for Williams et al. (1972) observed a marked difference in the response to methionine and cystine between sheep of a high or low wool-growth potential.

Tissue protein. The fact that the animals given supplementary protein made gains in tissue 


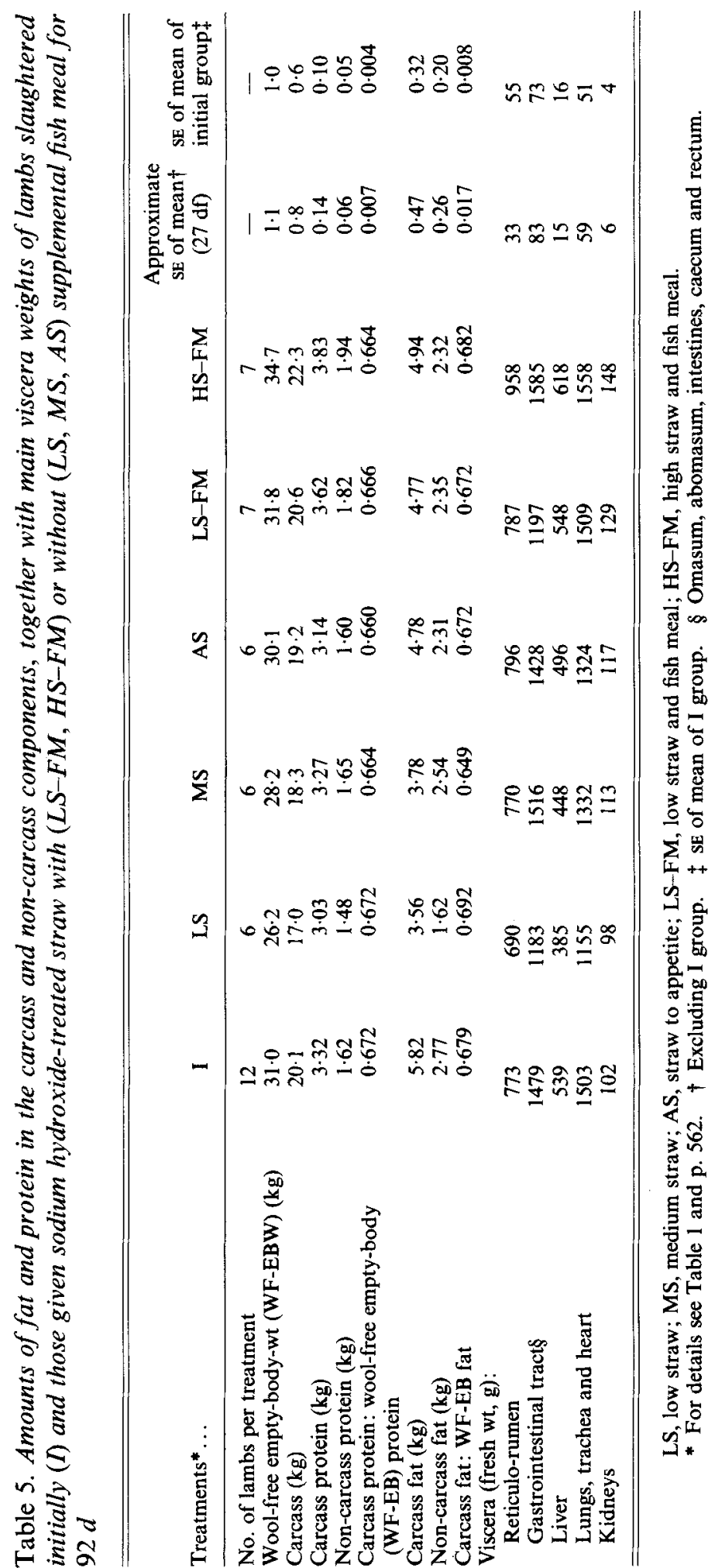




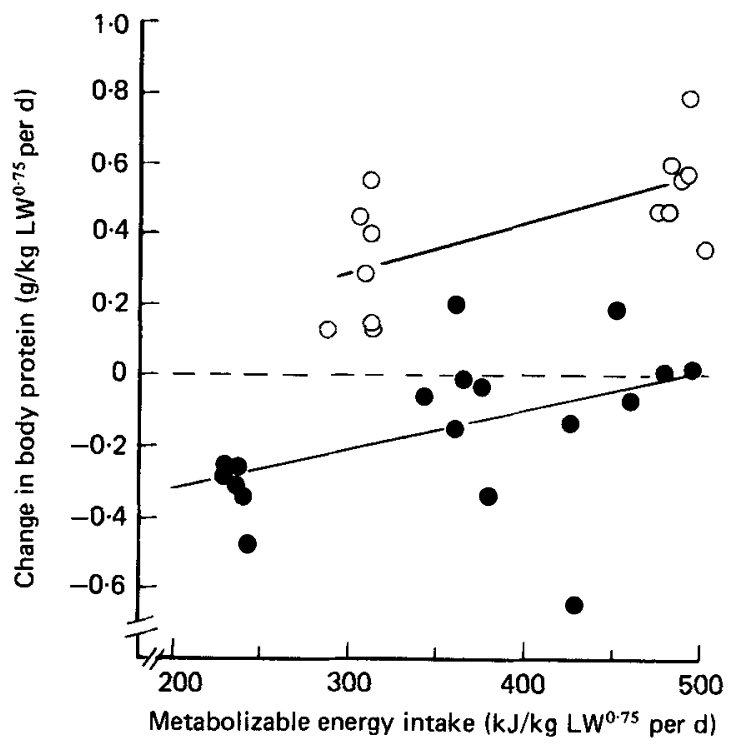

Fig. 2. Changes in wool-free whole-body protein ( $\mathrm{g} / \mathrm{kg}$ live weight $(\mathrm{LW})^{0 \cdot 75}$ per d) of wether lambs given sodium hydroxide-treated barley straw and urea with $(O)$ or without (O) $125 \mathrm{~g}$ white-fish meal/d for $92 \mathrm{~d}$.

protein while losing energy (Tables 3 and 4, and Fig. 2) is in agreement with the results of Hovell et al. $(1983 \mathrm{~b}$ ) who found that lambs entirely nourished by intragastric infusion could maintain a positive $\mathrm{N}$ balance at ME intakes substantially below accepted values for energy maintenance. It was postulated that the lambs had the ability to mobilize body fat and continue protein accretion provided there were available amino acids for tissue accretion and fat for mobilization.

The accretion of body protein at the expense of body fat is precisely what occurred with the lambs given supplementary protein in the experiment reported here. Thus the HS-FM animals lost $11 \%$ of body fat and $4 \%$ of WF-EB energy, but increased WF-EBW by $13 \%$ and WF-EB protein by $18 \%$. Black \& Griffiths (1975) analysed a number of N-balance experiments with lambs of up to $32 \mathrm{~kg} \mathrm{LW}$ which had been given liquid-milk-based diets either by sucking, or directly into the abomasum by infusion. The model they derived showed that provided there was sufficient dietary $\mathrm{N}$, positive $\mathrm{N}$ balance was obtained when ME intake was greater than $230 \mathrm{~kJ} / \mathrm{kg} \mathrm{LW}^{0.75}$ per d; well below energy equilibrium. Our results confirm that this principle can be extended to older, larger lambs and lambs which are also truly functioning ruminants. The fact that microbial protein supply was inadequate is demonstrated by the tissue losses of the lambs of the unsupplemented groups. Our results also emphasize that a positive $\mathrm{N}$ balance may be due to the deposition of wool protein when body protein is actually being depleted (as with the unsupplemented groups), but that an adequate supply of dietary protein will result in a true accretion in the lean body mass of the animal at the expense of body fat reserves.

Naismith \& Holdsworth (1980) also arrived at this conclusion on the basis of two experiments with rats, and the experiments of Fuller (1983) and Fowler et al. (1983) have shown the same effect with pigs. An interesting feature of the experiments of Naismith \& Holdsworth (1980) is that the $\mathrm{N}$ retention of rats given energy ad lib. remained relatively constant, while that of the rats restricted for energy fell during the $17 \mathrm{~d}$ of the experiment, implying that protein accretion when in negative energy balance may depend on the overall energy status of the animal. 
In the experiment reported here, the lambs not given supplementary protein were expected to lose protein at a greater rate than that observed. This assumption was based on our own estimate of basal tissue $\mathrm{N}$ metabolism (urine excretion) of $356 \mathrm{mg} \mathrm{N} / \mathrm{kg} \mathrm{LW}$ per d (Hovell et al. 1983a), and the estimate of the ARC (1980) for the provision of $\mathrm{N}$ of microbial origin $(1.25 \mathrm{~g} / \mathrm{MJ} \mathrm{ME})$. If the net utilization $(0.54)$ value of Storm et al. (1983) for microbial $\mathrm{N}$ is assumed, then $675 \mathrm{mg} / \mathrm{MJ} \mathrm{ME}$ would have been made available from microbial $\mathrm{N}$ to the lambs given the unsupplemented diet. Calculation from Table 4 shows that at a ME intake of $456 \mathrm{~kJ} / \mathrm{kg} \mathrm{LW}^{0.75}$ per d (that of the AS lambs), wool growth was equivalent to $62 \mathrm{mg} \mathrm{N} / \mathrm{kg} \mathrm{LW}^{0.75}$ (wool fibre at $0.165 \mathrm{~N}$ (ARC, 1980)) and body protein loss $5 \mathrm{mg} \mathrm{N} / \mathrm{kg} \mathrm{LW}^{0.75}$ daily. Microbial N supply (from above) would have been $308 \mathrm{mg}$, which by difference $(308+5-62)$ gives a basal tissue requirement of $251 \mathrm{mg} \mathrm{N} / \mathrm{kg} \mathrm{LW}$ L $^{0.75}$ per d. Similarly, the basal tissue requirements of the MS and LS lambs become 219 and $173 \mathrm{mg} / \mathrm{kg} \mathrm{LW}^{0 \cdot 75}$ per d.

It is possible that there may have been an adaptation by the lambs to protein deficiency as with humans (James, 1972; Viteri \& Torun, 1980) and in this context the reduced liver weights of MS and LS lambs (p. 568) are of interest. It is difficult to make measurements of basal excretion in ruminants fed normally due to the obligate relationship between energy intake and microbial protein synthesis. Limited information from our own laboratory (D. A. Grubb and E. R. Ørskov, unpublished results) showed no evidence of a time adaptation in the basal $\mathrm{N}$ excretion by totally infused lambs given maintenance energy but no protein for up to $20 \mathrm{~d}$. The conventional feeding trial reported here suggested a lower basal requirement by the (albeit more mature) normally fed lambs on the unsupplemented diet, and possible evidence of a progressive reduction in basal amino acid $\mathrm{N}$ requirement as the supply of energy and amino acid $\mathrm{N}$ were reduced. Alternatively, the ARC (1980) value of $1.25 \mathrm{~g}$ microbial N per MJ ME may be too low. Even so, progressively lower basal values for the MS and LS groups would remain (unless microbial yield changed).

However, the important points of the results presented here are that at ME intakes below the requirement for energy maintenance, microbial protein was not sufficient to maintain the protein status of the WF-EB (unsupplemented lambs), and that animals deficient in dietary energy responded to additional protein by increasing protein accretion (supplemented lambs).

Body fat. The losses of body fat by all the experimental lambs is the main component of their overall energy balance, and will be discussed in more detail as energy. In other experiments with farm animals, depletion of adipose tissue has usually been considered to occur in conjunction with the simultaneous depletion of muscle and other tissues (Leat \& Cox, 1980). However, this conclusion is based on experiments which have involved a general undernutrition, and thus the provision of protein has been less than that which would enable the animal fully to exploit its ability for protein conservation or accretion. The fact that an animal can increase body protein whilst depleting body fat is described by the model of Black (1974, 1983), and is implicit in the ARC (1981) recommendations for pigs.

Body energy and utilization of diets. All experimental groups made a net loss in body energy (or only a slight gain in the case of the HS-FM animals if wool is included). The $M E$ required to maintain the lambs at energy equilibrium (maintenance) was (from Table 4) 453 and $629 \mathrm{~kJ} / \mathrm{kg} \mathrm{LW}^{\mathrm{0} \cdot 75}$ per $\mathrm{d}$ for the supplemented and unsupplemented groups respectively. Much of the apparent difference between the two groups is due to the adoption of parallel slopes for, as shown in Fig. 3, there is the suggestion that any difference between the supplemented and unsupplemented groups was less when they were close to energy equilibrium. The separate regressions for energy retention $\left(Y ; \mathrm{kJ} / \mathrm{kg} \mathrm{LW} \mathrm{W}^{0 \cdot 75}\right.$ per d) $v . \mathrm{ME}$ intake ( $X ; \mathrm{kJ} / \mathrm{kg} \mathrm{LW}^{0.75}$ per $\mathrm{d}$ ) which were $Y=0.123 X-61$ and $Y=0.314 X-174$ for the groups which were supplemented and unsupplemented respectively, gave ME intakes at energy equilibrium of 496 ad $554 \mathrm{~kJ} / \mathrm{kg} \mathrm{LW}^{0 \cdot 75}$ per d. 


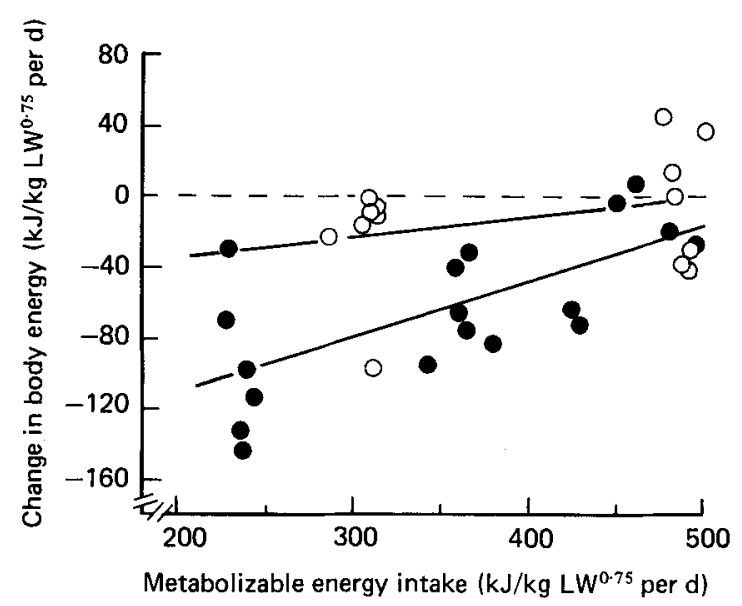

Fig. 3. Changes in whole-body energy (kJ/kg live-weight $(\mathrm{LW})^{0^{-75}}$ per $\left.\mathrm{d}\right)$ of wether lambs given sodium hydroxide-treated barley straw and urea with $(O)$ or without $(O) 125 \mathrm{~g}$ white-fish meal/d for $92 \mathrm{~d}$.

The efficiency with which ME was utilized to spare the catabolism of body energy reserves $\left(k_{m}\right)$ given by the slopes of the regressions $(0 \cdot 123$ (SE $0 \cdot 102$ ) and 0.314 (SE 0.084$)$ ) are very different from the $k_{m}$ of 0.7 calculated from ARC (1980) for a diet of metabolizability $(q)$ 0.54 (about that of the treated straw used here). A possible interpretation is that basal metabolism was related to ME intake. With a $k_{m}$ of 0.7 and energy losses (calculated from the regression on p. 571) of 31 and $100 \mathrm{~kJ} / \mathrm{kg} \mathrm{LW}^{0.75}$ per $\mathrm{d}$, the basal metabolism of the AS group becomes $(456 \times 0.7)+31=350 \mathrm{~kJ} / \mathrm{kg} \mathrm{LW}^{0.75}$ per $\mathrm{d}$ which agrees well with the ARC (1980) value of $370 \mathrm{~kJ} / \mathrm{kg} \mathrm{LW}^{0.75}$ per d for a $40 \mathrm{~kg}$ lamb. That of the LS group becomes $265 \mathrm{~kJ} / \mathrm{kg} \mathrm{LW}^{0.75}$ per d, approximately $76 \%$ of that of the AS group.

Basal metabolism cannot be measured directly in the fed ruminant and therefore is usually equated with fasting metabolism. The high intercepts at zero energy intake of the present experiment emphasize the dangers of simple extrapolation to the fasting state. There is evidence to show that fasting metabolism (when measured directly) is affected by the previous level of nutrition. Marston (1948), Graham et al. (1974), Farrell et al. (1972a, b) and Koong et al. (1982) showed fasting metabolism in sheep to be related to previous nutrition. Koong $e t$ al. (1982) suggested that part of the difference in fasting metabolism that they observed was due to a reduction in the size of the metabolically active organs. As shown in Table 5 (p. 568), we did not find large differences in viscera after correction for body size. Furthermore, the relative proportions of carcass and non-carcass protein remained constant (Table 5). It is interesting, however, that basal $\mathrm{N}$ requirement may also have been reduced (p. 571).

Although it is frequently possible to manipulate values to any desired level, a changing basal metabolism could explain the apparently poor utilization $\left(k_{m}\right)$ of additional ME by the lambs of the experiment reported here.

Effect of supplementation with protein. The effect of protein supplementation in reducing energy loss (Table 4) is more difficult to reconcile with current concepts of energy metabolism. Whether the results are examined as separate regressions (see p. 571) or with a combined slope (Table 4), there were statistically significant differences between the supplemented and unsupplemented groups. Values in Fig. 3 suggest that much of the difference between the supplemented and unsupplemented groups was due to the LS-FM treatment. Had these animals been the same as the unsupplemented animals, they would 
have lost $54 \mathrm{~kJ} / \mathrm{kg} \mathrm{LW}^{0 \cdot 75}$ per d more than their actual loss. This is equivalent to $2 \cdot 1 \mathrm{~kg}$ fat additional to the 1.53 (SE 0.55 ) $\mathrm{kg}$ actually lost (Table 3). Thus, although we may have obtained a chance result, the results suggest that the conservation of body protein when the lambs were in protein deficit may have been energetically more expensive than when protein supply was adequate.

\section{Practical implications}

Energy. The poor utilization of ME and the apparent energy sparing effect of supplemental protein are explicable if it is first assumed that basal energy metabolism is dependent upon energy intake and, second, that protein deficiency may incur in the animal greater energy costs. If either or both of these assumptions be true, then the whole concept of the use of fasting metabolism as the basis of a feeding system is called into question, for the fasting animal, as well as mobilizing body energy reserves, is also grossly protein deficient. Changes in basal heat production, however caused, could so affect the apparent utilization of the diet that it would become difficult to distinguish between apparent utilization for maintenance $\left(k_{m}\right)$, or fattening $\left(k_{f}\right)$.

Protein. The experiment reported here has demonstrated that, provided the animal has fat reserves and the potential for growth, supplementation with protein when in negative energy balance will result in the accretion of body protein and the depletion of body fat. The animal will continue preferentially to use amino acids for protein metabolism per se, rather than as a source of energy, even when in negative energy balance. In this respect growth is similar to lactation since protein accretion will continue at the expense of body fat reserves. Similarly, the mature or young animal can be expected to utilize supplementary protein very effectively to offset endogenous losses.

The authors wish to thank Mr I. McDonald for the statistical analysis of the results and Dr P. Reeds for helpful discussion. They are grateful to Miss N. Mossom, Messrs L. Melvin and $\mathrm{K}$. Inglis and to Miss M. Annand and her colleagues for the chemical analyses as well as the other colleagues involved in the preparation of the paper for publication. The fish meal was a gift of the International Association of Fish Meal Manufacturers, whose support is gratefully acknowledged.

\section{REFERENCES}

Agricultural Research Council (1980). The Nutrient Requirements of Ruminant Livestock. Slough: Commonwealth Agricultural Bureaux.

Agricultural Research Council (1981). The Nutrient Requirements of Pigs. Slough: Commonwealth Agricultural Bureaux.

Atkinson, T., Fowler, V. R., Garton, G. A. \& Lough, A. K. (1972). Analyst, London 97, 562-568.

Black, J. L. (1974). Proceedings of the Australian Society of Animal Production 10, 211-218.

Black, J. L. (1983). In Sheep Production. Proceedings, University of Nottingham 35th Easter School, pp. 21-58 [W. Haresign, editor]. London: Butterworths.

Black, J. L. \& Griffiths, D. A. (1975). British Journal of Nutrition 33, 399-413.

Colebrook, W. F., Ferguson, K. A., Hemsley, J. A., Hogan, J. P., Reis, P. J. \& Weston, R. H. (1968). Proceedings of the Australian Society of Animal Production 7, 397-401.

Davidson, J., Mathieson, J. \& Boyne, A. W. (1970). Analyst, London 95, 183-193.

Downes, A. M., Reis, P. J. \& Hemsley, J. A. (1976). In From Plant to Animal Protein, pp. 143-150 [T. M. Sutherland, J. R. McWilliam and R. A. Leng, editors]. Armidale, Australia: University of New England Publishing Unit.

Elimam, M. E. \& Ørskov, E. R. (1981). Animal Production 32, 386.

Farrell, D. J., Leng, R. A. \& Corbett, J. L. (1972a). Australian Journal of Agricultural Research 23, $483-497$.

Farrell, D. J., Leng, R. A. \& Corbett, J. L. (1972b). Australian Journal of Agricultural Research 23, $499-509$.

Fowler, V. R., McWilliam, R., Pennie, K. \& Ross, L. (1983). Animal Production 36, 517.

Fuller, M. F. (1983). Journal of Nutrition 113, 15-20.

Graham, N. McC., Searle, T. W. \& Griffiths, D. A. (1974). Australian Journal of Agricultural Research 25, $957-971$. 
Hovell, F. D. DeB., Orskov, E. R., Grubb, D. A. \& MacLeod, N. A. (1983a). British Journal of Nutrition 50, $173-187$.

Hovell, F. D. DeB., Ørskov, E. R., MacLeod, N. A. \& McDonald, I. (1983b). British Journal of Nutrition 50, $331-445$.

Institut National de la Recherche Agronomique (1978). Alimentation des Ruminants. Versailles: INRA Publications.

James, W. P. T. (1972). Proceedings of the Nutrition Society 31, 225-231.

Koong, L. J., Farrell, C. L. \& Nienaber, J. A. (1982). In Energy Metabolism of Farm Animals [A. Ekern and F. Sundstøl, editors]. European Association for Animal Production Publication no. 29. Lillehammer, Norway: Agricultural University of Norway.

Leat, W. M. F. \& Cox, R. W. (1980). In Growth in Animals, pp. 137-174 [T. L. J. Lawrence, editor]. London: Butterworths.

Marston, H. R. (1948). Australian Journal of Scientific Research 1(B), 93-129.

Mehrez, A. Z. \& Ørskov, E. R. (1977). Journal of Agricultural Science, Cambridge 88, 645-650.

Naismith, D. J. \& Holdsworth, M. D. (1980). Nutrition and Metabolism 24, 13-22.

Ørskov, E. R., Grubb, D. A., Wenham, G. \& Corrigall, W. (1979). British Journal of Nutrition 41, 553-558.

Ørskov, E. R. \& McDonald, I. (1979). Journal of Agricultural Science, Cambridge 92, 499-503.

Ørskov, E. R. \& MacLeod, N. A. (1982). British Journal of Nutrition 47, 625-636.

Reis, P. J. (1969). Australian Journal of Biological Sciences 22, 745-759.

Storm, E. \& Ørskov, E. R. (1983). British Journal of Nutrition 50, 463-470.

Storm, E., Ørskov, E. R. \& Smart, R. (1983). British Journal of Nutrition 50, 471-478.

Viteri, F. E. \& Torun, B. (1980). In Modern Nutrition in Health and Disease, 6th ed, pp. 697-720. [R. S. Goodhart and M. E. Shils, editors]. Philadelphia: Lea \& Febiger.

Williams, A. J., Robards, G. E. \& Saville, D. G. (1972). Australian Journal of Biological Sciences 25, $1269-1276$. 